\title{
A Critical Review on Improved Technologies for Maximization of Pulses Production in Rain Fed Areas
}

\author{
Monika Banotra*, B.C. Sharma, Brij Nandan, Rakesh Kumar and Akhil Verma \\ Division of Agronomy, SKUAST Jammu, Chatha, India \\ *Corresponding author
}

\begin{tabular}{|l|}
\hline Ke y w o r d s \\
$\begin{array}{l}\text { Technologies, } \\
\text { Maximization of } \\
\text { pulses, Rain fed } \\
\text { areas. }\end{array}$ \\
\hline Article Info \\
\hline $\begin{array}{l}\text { Accepted: } \\
\text { 23 September } 2017 \\
\text { Available Online: } \\
\text { 10 October } 2017\end{array}$ \\
\hline
\end{tabular}

A B S T R A C T
Out of 1.5 billion ha (11\% of the land surface) of crop land worldwide, 1.2 billion ha (82 $\%$ ) is rain fed. These regions cover about $40 \%$ of the world population; further $70 \%$ of the world's staple food continues to be harvested from rain fed areas Sharma (2011). India ranks first among the countries that practice rain fed agriculture. Out of the total geographical area of $328.73 \mathrm{~m}$ ha in India; only $143 \mathrm{~m}$ ha is under cultivation. Even after realising the complete irrigation potential of the country, $79.44 \mathrm{~m}$ ha $(57 \%)$ cultivated area is rain fed Anonymous (2014). Indian economy is passing through critical stage. Therefore performance of agriculture is critical to achieve and sustain higher growth rates that are required to address the goal of reducing poverty and underdevelopment. For agriculture to contribute to economy, contribution of rain fed agriculture should be increased. Therefore upgrading rain fed agriculture promises large social, economic and environmental paybacks, particularly in poverty reduction and economic development. Under these circumstances pulses have a special place in rain fed agriculture due to their low input requirement and inherent tolerance to inadequate soil moisture but their cultivation over poor, marginal and nutrient deficient soils, lack of moisture availability, socio-economic condition of the farmers, severe weed infestation are the major constraints in realizing the potential of available technologies for the pulse production.

\section{Introduction}

Pulses constitute an important group of food plaths in the world. They are the most important source of proteins not only for human population but also for herbivores. Pulses are important part in balanced diet because of their high nutritional value.

They are rich source of proteins, essential nutrients but low in fat content. Due to low fat content pulses are recommended to be included in the diet of people suffering from diabetics and heart patient. Pulses contribute substantially to food production system by enriching the soil through biological nitrogen fixation and improving the physical conditions. They are rightly called "unique jewels' of Indian crop Kumar et al., (2010). There are many constraints for the low yield of pulses in the rain fed areas these include lack of appropriate moisture, lack of timely sowing and proper sowing methods, lack of balanced fertilizer and weed control methods. Therefore for maximization of pulses production in rain fed areas improved technology for moisture conservation, timely planting of crops, adoption of improved 
varieties, weed management, integrated nutrient management, method of fertilizer application, growth hormones need to be focus. Therefore relevant review on improved technologies for maximization of pulses production in Rain fed areas have been presented here

\section{Effect of moisture conservation in improving yield of pulses}

Mulches are used for various reasons in agriculture but moisture conservation and erosion control are the most important objectives. Mulching reduces the deterioration of soil by way of preventing the runoff and soil loss, minimizes the weed infestation and reduces water evaporation. Thus, it facilitates more retention of soil moisture and helps in control of temperature fluctuations, improves physical, chemical and biological properties of soil, as it adds nutrients to the soil and ultimately enhances the growth and yield of crops.As per the experimental results of Selvi et al., (2009) while studying the effect of agronomic management for pigeon pea under drought conditions of Tamil Nadu depicts that significantly higher grain yield was recorded in the treatment viz., application of RDF + cultural mulch two times during both the years of study kharif (2004) and kharif (2005).

This was mainly due to the favourable soil atmosphere created by the cultural mulches by reducing the soil evaporation and improving better uptake of nutrients. Similar studies were also reported by Panian et al., (2001). Reducing the fertilizer dose to half was not found beneficial. The response was not good for seed soaking with either $2 \%$ $\mathrm{Cacl}_{2}$ or $2 \% \mathrm{Kcl}$ during both the year of study. This may be due to the early and uniform germination leading to the better establishment caused by $\mathrm{Ca}$ and $\mathrm{K}$. Experimental studies conducted by
Sabyasachimitra and bhattacharya (2005) while studying the study of water use and productivity of green gram (Vigna radiate var. radiata) as influenced by spacing, mulching under rain fed upland situation of Tripura for two years stated that row spacing of $45 \mathrm{~cm}$ recorded higher depletion of stored soil moisture and subsequently increased the consumptive water use by green gram than 25 $\mathrm{cm}$ row spacing, while the water use efficiency was more with the latter. The highest grain yield $(0.55 \mathrm{t} / \mathrm{ha})$ and $(0.35 \mathrm{t} / \mathrm{ha})$ in $25 \mathrm{~cm}$ row spacing which was probably owing to higher plant population and subsequently lesser weed interference under close spacing whereas mulching @5 t/ha resulted in higher grain yield $(0.51 \mathrm{t} / \mathrm{ha})$ and $(0.38 \mathrm{t} / \mathrm{ha})$ of green gram over no mulch. This was due to higher reduction in weed biomass with mulching because mulch suppresses the weed growth at all phenophases. Similar findings were also reported by Mahmood and Cheema (2004) and veeramani et al., (2000)

Study conducted by Roy et al.,(2015), to study the effect of different moisture conservation techniques with Phosphate solubilising and mobilizing microbes on productivity of rain fed chickpea on slightly acidic soil of West Bengal state that application of moisture conservation techniques and bio fertilizer inoculation. Application of straw mulching @ 5t/ha recorded significantly higher number of pods/plant, number of grains per plant (32) and test weight (219.8 g) and grain yield (1634 kg/ha) as compare to control, Kaolin $6 \%$ and PMA. This was might be due to more favourable condition under straw mulching. Whereas the highest number of pods/plant (21.1), grains /plant (34.9), highest test weight $(234 \mathrm{~g})$ and grain yield (1653 kg/ha) was recorded with inoculation of PSB + VAM and it was significantly greater than that of the crop under PSB, VAM and control. The increase in number of pods /plant in PSB + 
VAM were might be due to dry matter production that could be ascribed to a better translocation of photosynthates towards the yield attributes, and the highest grain weight was might be due to the synergistic effect between PSB and VAM that encouraged proper crop growth and assimilate synthesis in the grain. It is well known that PSB produce Vitamins and IAA, GA like growth substances. These growth factors in combination with the better nutritional condition due to increased availability of Phosphours might in soil have played a role in increasing the grain yield. VAM not only supplies essential nutrients but also water to plants resulting in better growth that led to increasing grain yield. Yadav and Shrivastava (1997) recorded similar findings.

\section{Effect of cultural practices in improving yield of pulses}

The low yield of pulses in the rain fed areas may due to several a biotic and biotic factors. The yield loss in pulses due to these factors varies up to 30 to $60 \%$ depending upon the type of variety grown, climatic condition, planting time, seed rate and spacing. Some cultivars of pulses have capacity to tolerate drought in that case the sowing is delayed but early or delayed sowing causes drastic reduction in yield as compared to timely sowing. Therefore for maximizing the yield of pulses in the rain fed areas cultural practices like timely sowing, proper seed rate, spacing, method of sowing also be considered.

According to the results of Roy (2005), while studying the effect of planting method on growth and seed yield of chickpea under rain fed condition for two years observed that significant difference was recorded with respect to number of plant $/ \mathrm{m}^{2}$, pods/plant, dry weight per plant (g) and seed yield (t/ha).Significantly highest yield (2.50 t/ha) and (3.38 t/ha) was recorded with Drilling +5 $\mathrm{cm}$ mulch (thick straw and water hyacinth), whereas the lowest seed yield ( $2.40 \mathrm{q} / \mathrm{ha})$ and (2.81 q/ha) was obtained from broadcasting. The highest seed yield in chickpea was might be due to the reason that straw + water hyacinth mulched conserved more moisture, kept the soil cool to some extent and favoured seed yield. These results were in consistent with Droughton et al., (1993).

Insanullah et al., (2002), while studying the effect of sowing dates on yield and yield components of Mash Varieties observed that maximum number of pods per plant (30.2) was recorded in plots sown on July 01, while minimum pods/plant (9.4) for August 01 sowing. Among the varieties the highest number of pods per plant (20.6) was observed for Mash-1.This was might be due to the difference in genetic potential of varieties. Sowing dates and varieties were significantly influenced by number of seeds per pod. Grain yield followed the same pattern those observed in pods/plant, seed /pod as grain yield decreased in both before and after July01 sowing. Planting date and varieties significantly influenced the grain yield. The highest grain yield $(825 \mathrm{~kg} / \mathrm{ha})$ was recorded in plots sown on July 01. The lowest grain yield $(278.1 \mathrm{~kg} / \mathrm{ha})$ was observed in plots sown on August 15.The highest grain yield was might be due to the reason that early planted crop had sufficient time for its growth and development. Similar results were also reported by Chaudhary et al., (1994) and Mittal (1999).

Khattak and Khan (2005) conducted experiment on chickpea in district karak and observed that maximum chickpea yield (1968 $\mathrm{kg} / \mathrm{ha}$ ) was recorded with treatment CPTC2 (Chisel plough once and Tine type cultivator twice) whereas minimum chickpea yield was recorded with no-till (1695 kg/ha). The increase in yield with CPTC2 was might be due to better control of weeds and improved soil moisture which ultimately led to higher chickpea yield. 
According to the results of the study conducted by Ahmad et al., (2004) on growth and yield response of three Mung bean (Vigna radiata) cultivars to varying seed rates revealed that plant population varied significantly by increasing seeding densities. Seed rate of $25 \mathrm{~kg} / \mathrm{ha}$ gave significantly the maximum plant population per plot (313) against minimum (238) for $15 \mathrm{~kg}$ seed/ha. This was because plant population increased with increase in the seed rate. Cultivar NM-98 produced the highest grain yield (983.75 $\mathrm{kg} / \mathrm{ha}$ ) which was at par with NM-92 (972.23 $\mathrm{kg} / \mathrm{ha}$ ). Seed rate of $25 \mathrm{~kg} / \mathrm{ha}$ produced significantly the highest grain yield of $1004.36 \mathrm{~kg} / \mathrm{ha}$ due to optimum plant population. These results are in line with the findings of Singh et al., (1998).

Khan et al., (2010) studied the effect of row spacing and seeding rates on growth yield and yield components of chickpea under sandy loam soil of Punjab Pakistan and revealed that maximum average number of pods /plant (45.61), seeds/pod (1.957), 100-seed weight (31.73 g) was recorded with 45 row spacing $\mathrm{x} 75 \mathrm{~kg}$ seed rate/ha

\section{Effect of nutrient management in improving yield of pulses}

The rain fed are low in soil fertility therefore both macronutrient and micronutrient are essential for increasing the productivity of the pulse crops. Pulses require nutrients for root growth, growth of rhizobia, for the growth and development of nodule, pod formation, protein synthesis, nitrogen fixation and assimilation and reproduction processes.

Thesiya et al., (2013) conducted experiment on instructional farm of college of Agriculture, Junagadh Agricultural university to study the effect of potassium and sulphur under rain fed condition observed that application of $20 \mathrm{~kg} \mathrm{~K} \mathrm{~K}_{2} \mathrm{O}$ /ha recorded the maximum plant height and number of branches which was significantly higher over control ( $\left.0 \mathrm{~kg} \mathrm{~K} \mathrm{~K}_{2} \mathrm{O} / \mathrm{ha}\right)$. The increase in plant height could partly be attributed due to the beneficial effect of potash fertilization. Potash is known to augment cell division and cell expansion resulting in increasing positive effect on growth parameters. The $20 \mathrm{~kg} \mathrm{~K}_{2} \mathrm{O}$ registered the highest number of grains/pod, 100-grain weight (g) and grain yield per plant. However it was remained at par with $40 \mathrm{~kg}$ $\mathrm{K}_{2} \mathrm{O} / \mathrm{ha}$ in yield attributing characters. This trend was might be due to the fact that the soil under experiment was medium in available potash and response was restricted to $20 \mathrm{~kg}$ $\mathrm{K}_{2} \mathrm{O} /$ ha. It was also observed that the straw yield remarkably increased in $20 \mathrm{~kg} \mathrm{~K}_{2} \mathrm{O}$ /ha than rest of potash levels. The positive effect of potash on straw yield may be due to the pronounced role of potash in photosynthesis and cell elongation. These results were in conformity with Laltlanmawia et al., (2004).Whereas plant height and number of branches of black gram was significantly influenced by different levels of sulphur. The significantly higher number of branches per pant and plant height was recorded with application of $30 \mathrm{~kg} \mathrm{~S} / \mathrm{ha}$. This might be due to known role of sulphur in stimulation of cell division, photosynthetic process as well as formation of chlorophyll. It promotes the root nodule in legumes, which cause the more sulphur available during the vegetative growth period and development of plant occurs.

The application of $30 \mathrm{~kg} \mathrm{~S} / \mathrm{ha}$ gave the highest value of number of grains per pod, 100 seed weight. However, application of 45 $\mathrm{kg} \mathrm{S} / \mathrm{ha}$ remained at par with $30 \mathrm{~kg} \mathrm{~S} / \mathrm{ha}$. Increasing in different yield attributing characters might be due to more availability of sulphur during these vegetative and reproductive stages of the crop. Sulphur is an important part of amino acid (Cystine), which helps in the chlorophyll formation, photosynthetic process and activation of many enzymes and grain formation. The highest 
yield grain yield of $9.19 \mathrm{q} / \mathrm{ha}$ was proved significantly over the rest of treatments. The increase in grain yield of sulphur with increasing level of sulphur might be due to vital role played by sulphur in accelerating the yield attributes. These results were direct in line with the result of Srinivasan and Sankaran (2001) in black gram.

According to the results of Neenu et al., (2014) while working on growth and yield of different varieties of chickpea as influenced by the phosphorus nutrition under rain fed conditions on Vertisol of Madhya Pradesh observed that although there was no significant difference in seed yield among the varieties with the application of either 60 or $90 \mathrm{~kg} \mathrm{P}_{2} \mathrm{O}_{5}$ were on par and produced significantly higher seed yield over the other doses of $\mathrm{P}$. The plausible reasons for increase in seed yield under either 60 or $90 \mathrm{~kg} / \mathrm{ha}$ could be that phosphorus is essential for cell division development of root nodules and stimulation of nitrogen fixation. Similar results were also reported by Patil et al., (2002).

Singh and Singh (2014) while evaluating the effect of integrated nutrient management on growth, physiological parameters and productivity of lentil (Lens culinaris Medik) during rabi season at Sehore (M.P) observed that the factors which are directly responsible for ultimate grain production viz., number of pods/plant, number of seeds per pod and test weight were augmented significantly due to increased supply of nutrients from integrated nutrient management treatments having NPKS@ 20:40:20:20 kg/ha + 5 FYM @ 5 t/ha. Highest pods/plant (84.07), seeds/pod (2.19), test weight $(3.30 \mathrm{~g})$, grain yield $(1071 \mathrm{~kg} / \mathrm{ha})$ and straw yield $(1839 \mathrm{~kg} / \mathrm{ha})$ was recorded with treatment NPKS@ 20:40:20:20 kg/ha + 5 FYM @ 5 t/ha which was found statistically at par with integrated nutrient management treatment having NPKS @ 20:40:20:20 kg/ha + Vermicompost@2t/ha and NPKS
@ 20:40:20:20 kg/ha + Rhizobium + PSB in yield and yield attributing characters. This was might be due to the reason that the organic sources like FYM or Vermicompost are the store house of plant nutrients which might have improved the physic chemical as well as biological properties of the soil to enhance the crop yield. On the other hand, for the soils applied only chemical fertilizers are deprived of all these advantages necessary for more production of functioning of leaves, greater accumulation of carbohydrates, protein translocation to the reproductive organs, which in turn increased the number of pods/plant and other associated yield attributing parameters. These results are in conformity with the findings of Sharma and Verma (2011).

Jha et al., 2015, while studying the effect of organic and inorganic nutrients on yield and economics of black gram during kharif season at Udaipur, Rajasthan and reported that the yield attributes and yield increased significantly with the application of organic and inorganic nutrients in black gram over control. the yield attributing characters i.e number of pods (32.38/plant), number of seeds (6.88/pod) of black gram increased significantly with $100 \% \mathrm{RDF}+\mathrm{Zn}+\mathrm{Fe}$ (N:P:K-20:30:15 kg/ha + ZnSO $45 \mathrm{~kg} / \mathrm{ha}+$ $\mathrm{FeSo}_{4}$ ). Application of $100 \% \mathrm{RDF}+\mathrm{Zn}+\mathrm{Fe}$ significantly increased seed yield by 33.91 and $8.75 \%$ over $75 \%$ RDF and $100 \%$ RDF. The combined application NPK $+\mathrm{Zn}+\mathrm{Fe}$ rates to the black gram increased availability of major and minor nutrients to plant might have enhanced early root growth and cell multiplication leading to more absorption of other nutrients from deeper layers of soil ultimately resulting in increased plant growth attributes and finally increased crop growth rates. The increased seed yield attributes and yield might be due to the increased supply of the major nutrients by translocation of photosynthates accumulated under the influence of the sources of inorganic 
nutrients. These results were in line with the results of Rathore et al., (2010).

Rao et al., (2015) studied the effect of integrated weed management practices on growth and yield of pigeon pea during rainy season at RAMS Lam, Guntur, India and observed that maximum values of growth parameters, yield components and grain yield (2647 kg/ha) was recorded under weed free situation which was closely followed by IWM treatments viz., integration of pendimethalin $@ 0.75 \mathrm{~kg}$ a.i./ha PE and imazathapyr @ 100g a.i. /ha POE.

\section{Effect of weed management in improving yield of pulses}

The inadequate weed control measure are also responsible for low yield of pulses in the rain fed areas. The weeds which grow at the same time with crop grow very fast and offer competition with pulse crop at all the stages. This results in decrease in the yield of pulses. Therefore, it becomes crucial to control at the early stages to maximize yield and to reduce crop weed competition.

Patel et al., (2006), while studying the effect of fertilizers and weed management practices on weed control in chickpea (Cicer arietinum) under mid hills of Gujarat on sandy loam texture observed that number of pods per plant and 100 seed weight of chickpea was found non-significant due to fertilizer treatments whereas seed and straw yield were significantly influenced due to different fertilizer treatments. Application of $5 \mathrm{t} / \mathrm{ha}$ FYM and 5 t/ha FYM $+1.5 \mathrm{~kg} / \mathrm{ha} \mathrm{MO}$ were found superior and registered significantly higher seed yield of (1226 kg/ha) and (1224 $\mathrm{kg} / \mathrm{ha}$ ) as compared to all other treatments. This was might be due to the positive effect of FYM application on yield of chickpea whereas application of Molybdenum alone or in combination with FYM marginally increases in number of pods/plant as compared to control could be due to the enhanced nitrogen fixation and reduction. The higher Stover yield (1494 kg/ha) under application of 5/ha FYM was probably due to the marginally increase in plant height, number of branches per plant which led increase in biomass of crop. Similar results were also reported by Raju et al., (1998).

Results further revealed that difference due to different weed management practices in respect of number of pods/plant and 100 seed weight were significant. Application of oxadiargyl@0.075 kg/ha recorded significantly higher number of pods (39.88) and seed weight as compared to weedy check treatment. This was might be due to the effective control of weeds at critical cropweed competition stages which might have helped in increasing nutrient uptake and there by the crop growth and formation of bold seeds and consequently increase in weight of 100-seed weight. The highest seed yield (1409 kg/ha) and straw yield (1685 kg/ha) were recorded significantly higher under Inter culture + Hand weeding at 20 and 40 DAS which was found statistically at par with seed yield (1383 kg/ha) and stover yield (1649 $\mathrm{kg} / \mathrm{ha}$ )obtained from treatment oxadiargyl $@ 0.075 \mathrm{~kg} / \mathrm{ha}$ and were found significantly superior as compared to rest of the treatments, this was might be due to the fact that effective control of weeds lead to direct increase in uptake of nutrients and their by proper growth and development of crop which resulted in maximum number of pods/plant and test weight ultimately resulting into increased seed yield. These results were in line with the results of Upadhay and Bhalla (2002).

Aggarwal and Ram (2011) while studying the effect of nutrients and productivity of lentil (Lens culinaris L.) on sandy loam soil of Nariangrh for two consecutive rabi season and observed that FYM @15 t/ha + RDF 
resulted in significantly higher plant height $(30.3 \mathrm{~cm})$, branches/plant $(8.27)$, number of pods/plant (46.3) of lentil as compared with other treatments whereas nutrient use efficiency was highest in 15 tones FYM along with RDF and was 15.1 per cent and 10.9 per cent higher than alone FYM and RDF. This was might be due to better nutrition of the plant. Among the weed control treatments the highest plant height $(32.0 \mathrm{~cm})$, branches/plant (9.08), pods/plant (50.9) and biological yield $(3143 \mathrm{~kg} / \mathrm{ha})$ was recorded with treatment 2 hand weeding (20 and 30 DAS).Hand weeding twice at $30 \& 60$ DAS resulted in better vegetative and reproductive growth of lentil than other weed control treatments. These results were in conformity with the findings of Sadiq et al., (2002).

Madukwe et al., (2012) while studying the effects of weed control methods on the growth and yield of cowpea (Vigna unguiculata) under rain fed conditions of Owerri revealed that highest number of pods/plant (51.46), 100-seed weight (g),mean seed yield (2901 kg/ha) and lowest weed biomass $\left(\mathrm{g} / \mathrm{m}^{2}\right)$ was recorded with treatment chemical weeding at 2-3leaf stage of weed + hand weeding at 50 DAP followed by mechanical weeding at 20 DAP + hand weeding at 50 DAP whereas highest weed biomass $\left(101.2 \mathrm{~g} / \mathrm{m}^{2}\right)$ and lowest number of pods/plot (25.50), 100-seed weight (g) (10.5 g) and mean seed yield (2160 kg/ha) was recorded with weedy check. This was might be due to the fact that this treatment could be associated with the higher number of leaves and leaf area recorded. The higher number of leaves and leaf area could have made way for greater interception of light which encouraged photosynthetic process of the plants which was required for pod filling and improved yield. These results were in conformity with Chattha et al., (2007). Kaushik et al., (2013) conducted experiment to study the growth, yield and economics of rain fed chickpea at
Satna Madhya Pradesh observed that the highest plant height $(31.60 \mathrm{~cm})$, yield attributes viz., pods /plant (38.33), seeds/pod (1.35) and seed yield (14.89 q/ha) was recorded with integrated weed control method pendimethalin@0.75 kg/ha Pre-E + HW25 DAS.

Singh and Sekhon (2013) studied the effect of integrated weed management in Pigeon pea and observed that two hand weedings, Pendimethalin in integration with hand weeding or ridging or both and Paraquat in integration with hand weeding resulted in high weed control efficiency. Integration of pendimethalin $0.45 \mathrm{~kg} / \mathrm{ha}+$ hand weeding 30 DAS + ridging 50 DAS provided the highest grain yield of Pigeon pea.

Chhodavadia et al., (2014) while studing the effect of integrated management for improved weed suppression in summer green gram (Vigna radiate L.) at Junagadh (Gujrat) observed that maximum number of pods/plant (15.4), number of grain /pod(7.03), grain weight /plant, 100-seed weight (35.96) were significantly found in the treatment two HW and IC at 20 and 40 DAS which was followed with the treatments like Oxyfluorfen 0.180 $\mathrm{kg} / \mathrm{ha}+$ one hand weeding at $30 \mathrm{DAS}$, one HW and one IC at 30 DAS and quizalofop ethyl at 20 DAS. This was might be due to the reason that number of pods/plant is a varietal character but tremendous weed infestation caused stress to the crop plant with respect to nutrient, light, moisture space and other various aspects related to physiological process of crop plant and thus enforced the crop to have less number of pods per plant and this was highly evident in weedy check treatment. Highest grain and Stover yield was recorded in weed free $1004 \mathrm{~kg} / \mathrm{ha}$ and 1416 $\mathrm{kg} / \mathrm{ha}$ which was followed with two HW and two IC at 20 and 40 DAS (977 kg/ha and $1376 \mathrm{~kg} / \mathrm{ha}$ ) and oxyfluoren $0.180 \mathrm{~kg} / \mathrm{ha}+$ one $\mathrm{HW}$ at 30 DAS $(957 \mathrm{~kg} / \mathrm{ha})$, it may be 
expressed that higher weed infestation was responsible for reducing seed yield, as the treatments with higher weed intensity were with lower seed yield during the summer season. Similar results were also reported by Vivek et al., (2008).

Yadav et al., (2015) while studying weed management effects on yield and economics of black gram on sandy loam texture of Gwalior Madhya Pradesh observed that significantly higher seed yield (0.89 t/ha) and straw yield (2.91 t/ha) was recorded with weed free plot over all the treatments, which was followed by imazethapyr + imazamox (premix) at $0.05 \mathrm{~kg} / \mathrm{ha}$ as $(0.84$ and 2.89 /ha)and pendimethalin + imazethapyr (pre$\operatorname{mix})$ at $1.0 \mathrm{~kg} / \mathrm{ha}(0.80$ and $2.82 \mathrm{t} / \mathrm{ha})$ treatments.

\section{Effect of growth hormones in improving yield of pulses}

One of the recent techniques in increasing the yield of pulses is the use of growth hormones. The growth hormones help in increasing the productivity of pulses by affecting the vital physiological processes like affecting portioning of assimilates, stimulating root development, nodule formation, energy transformation, various metabolic processes and increasing pod setting and their by maximizing yield.

Kumar et al., (2013) while studying the effect of growth regulator, organic and inorganic foliar nutrition on growth and yield of black gram under rain fed condition observed that the highest yield attributes viz., number of pods/plant (38.73), seeds/pod (6.47), test weight $(61.90 \mathrm{~g})$ and grain yield $(1298 \mathrm{~kg} / \mathrm{ha})$ was recorded with treatment basal application of RDF + foliar spray of $40 \mathrm{ppm}$ NAA + 0.5 $\%$ chelated micronutrient $+2 \%$ DAP. The increase in growth with this treatment was might be due to the fact that foliar application of NAA promoting the apical dominance, cell elongation and shoot development whereas foliar application of chelated micronutrient enhances the synthesis of carbohydrates and protein. In addition foliar application of DAP at critical stages of the crop enhanced better photosynthetic as reported by Subramani et al., (2002).

Kumar et al., (2015) while studying the role of growth boosters on the yield of Urd bean (Phaseolus mungo) at dharwad reported that lowest pods per plant (6.00) observed from Rhizobium inoculation alone followed by control (5.0) treatment. Maximum pods per plant (8.66 pods/plant) were obtained from the spray of Aminos + Planofix treatment followed by aminos + tracel (8.33pods/plant) Aminos + Biozyme (8.13) pods/plant and Biozyme + Planofix (7.96 pods/plant) among applied growth boosters in combination. Highest grain yield (10.66q/ha) were obtained from the combined application of aminos + tracel (10.35 q/ha), aminos + biozyme (10.26 q/ha), biozyme + planofix (9.95 q/ha). Among single applied growth boosters highest yield (9.32 q/ha) were found from the aminos and followed by planofix $(9.11 \mathrm{q} / \mathrm{ha})$, tracel $(8.86$ q/ha) and biozyme (7.86 q/ha).Similar results were also reported by Mahala et al., (2001).

Gupta and Saxena (2015) studied the resource management in cowpea for yield maximization under rain fed condition of durgapura, Jaipur Rajasthan during kharif season revealed that foliar application of urea and mulching @3t/ha at 25-30 DAS had significantly influenced on yield attributes (pods/plant), seeds/pod and seed index and seed yield of cowpea. The maximum pods/plant (6.48), seeds/pod (8.58) and seed index (11.26)g was recorded under foliar application of 2\%urea at 25-30 DAS closely followed by foliar application of $1 \%$ urea and mulching@ @ t/ha but was significantly superior over normal sowing, seed inoculation with PSB and control. 


\section{References}

Aggarwal, N., and Ram, N. 2011. Effect of nutrients and weed management on productivity of lentil (Lens culinaris L.) Journal of crop and weed. 7(2):191-194.

Ahamad, R., Mahmood, I., Kamal, J. and Bukhari, S.A.H. 2004. Growth and yield response of three mung bean (Vigna radiata L.) cultivars to varying seed rates. International Journal of Agriculture \& Biology. 06(3):538-540.

Anonymous. 2014. Agricultural statistics at Galance. pp 58-202.-Government of India, Ministry of Agricultur, department of Agriculture \&Cooperation, Directorate of Economics and Statistics.

Chattha, M.R., M.Jamit and T.Z.Mahmood, 2007. Yield and yield components of cowpea as affected by various chemical control methods and rain fed condition of Pakistan. International Journal of Agricultural and Biology. 9 (1):120124.

Chaudhary, D.C., R.P. Singh and N.P. Singh, 1994. Growth behaviour of Urd bean varieties in relation to planting dates. Legume Research.17:124-126.

Doughton, J.A., Vallis, I. and Saffigna, P.G. 1993. Nitrogen fixation in chickpea. Influence of prior cropping fallow, nitrogen fertilizer and tillage. Australian Journal of Agricultural Research. 44:1403-1413.

Gupta, K.C., and Saxena, R. 2015. Resource management in cowpea (Vigna unguiculata L. Walp) for yield maximization under rain fed conditions. Journal of crop and weed. 11:146-148.

Gupta, K.C., and Saxena, R. 2015. Resource management in cowpea (Vigna unguiculata) for yield maximization under rain fed conditions. Journal Crop and Weed, 11(Special Issue):146-148.

Ihsanullah, Jan, A., TaJ, F.Y., Khan I.A., and
Khan,N.2002. Effect of sowing dates on yield and yield components of Mashbean Varieties. Asian Journal of Plant Sciences, 1(6): 622-624.

Kaushik, S.S., Rai, A.K., Sirothia, P., Sharma, K., and Shukla. 2013. Growth, yield and economics of rain fed chickpea (Cicer arientinum L.) as influenced by integrated weed management. Indian

Khattak, M. K., and Khan, M.J.2005.Effect of different tillage practices on weeds and yield of chickpea under sandy loam conditions. Pak. J. Weed Sci. Res. 11(34): 157-164.

Kumar, P., Peshin, R., Nain, M.S. and Manhas, J.S. 2010. Constraints of pulses cultivation as perceived by the farmers. Rajasthan Journal of Extension Education, 17: 33-36.

Kumar, S., Basavarajappa, R., Salakinkop, S.R., Hebbar, M., Basavarajappa, M.P., and Patil, H.Y., 2013. Effect of growth regulators, organic and inorganic foliar nutrition on the growth and yield of blackgram (Vigna mungo L.) under rain fed condition. Karnataka J. Agric.Sci.26 (2):311-313.

Kumar, S., Katiyar, A.K., and Kumar A. 2015. Role of growth boosters on yield of urd bean (Phaseolus mungo). International Journal of Plant Sciences, 10(1): 74-79.

Laltlanmawia, L., et al., 2004. Journal of Indian society of soil science, 52:199202.

Madukwe, D.K., Ogbuehi, H.C. and Onuh, M.O. 2012. Effects of weed control on the growth and yield of cowpea (Vigna unguiculata) under rain fed conditions of owerri. American -Eurasian Journal of Agricultural and environmental Science, 12(11):1426-1430.

Mahmood, A., Cheema ZA.20004. Influence of sorghum mulch on purple nutsedge (Cyperus rotundus L.) International Journal of Agriculture and Biology, 6 
(1):86-88.

Mittal, R.K., 1999. Cultural management of foliar disease of black gram hills of Uttar Pradesh. Journal of Mycology and plant Pathology, 29:128-130.

Neenu, S., Ramesh, K., Ramana, S., Biswas, A.K., and Rao, A.S. 2014. Growth and yield of different varieties of chickpea (Cicer arientinum) as influenced by the phosphorous nutrition under rain fed conditions on vertisols. International Journal of Bio-resource and Stress Management, 5(1):53-57

Pandian, B.J., et al., 2001. Madras Agricultural Journal, 88:406-409.

Patel, B.D., Patel, V.J., Patel, J.B., Patel, R.B., 2006. Effect of fertilizers and weed management practices on weed control in chickpea (Cicer arietinum L.,) under middle Gujarat conditions. Indian Journal of Crop Sciences, 1(12):180-183.

Patil, R.J., Dudhade, D.O., Patil, J.V., 2002. Response of chickpea to Phosphorus under varying moisture regime. Agricultural Science Digest, 22(2), 130131.

Raju, M.S., Verma, S.C and Ramaiah, N.V. 1998. Effect of phosphorus in relation to F.Y.M. vs. Rhizobium inoculation on nutrient uptake of chickpea cultivars under rain fed condition. Indian Journal of Agricultural Research, 25:43-48.

Rao, P.V., Reddy A. Subbarami and Rao.Y.K.2015.Effect of integrated weed management practices on growth and yield of pigeon pea (CAJANUS CAJAN (L.) MILLISP.). International Journal of Plant, Animal and Environmental Sciences.5(3):124-127.

Rathore, R.S., Singh, R.P. and Nawange, D.D.2010. Effect of land configuration, seed rates and fertilizer doses on growth and yield of black gram (Vigna mungo(L.) hepper). Legume Research,33:274-278.
Roy, A., Pramanik, K., Bera, A.K., Mukherjee, S., Dey, S. and Panda, D. 2015. Effect of different soil moisture conservation techniques with phosphate solubilising and mobilizing microbes on productivity of rain fed chickpea under rainfed condition of West Bengal. International Journal of Bioresource, Environment and Agricultural Sciences, 1(3):70-76.

Roy, S.K. 2005. Effect of planting method on growth and seed yield of chickpea under Rainfed conditions. Proceedings of Agronomy society of N.Z, (25):59-66.

Sabyasachimitra and Bhatytacharya, B.K.2005. Water use and productivity of green gram (Vigna radiate var. Radiata)as influenced by spacing mulching and weed control under rain fed upland situation of Tripura. Indian Journal of Agricultural Sciences, 75(1):52-54.

Sadiq, M., Jamil, M., Mehdi, S.M., Sarfraj, M., Gondal, M.R.andHassan, G.2002.Effect of various weedicides on weed control and yield of lentil (Lens Culinaris) crop in salt affected soil. Asian J.Pl.Sci, 1:215-16.

Selvi, R.V., Srinivasan, S.,Ramasamy,M.and Marimuthu.2009.Agronomic management of pigeon pea under rain fed conditions. Legume Research, 32(2)-139-141.

Sharma, K.D., 2011. Rain-fed agriculture could meet the challenges of food security in India, Current science, (100): 1615-1616.

Singh, D., J.P.Sahu and D.Singh, 1998.Performance of Mung bean genotypes under different seed rates during spring. Indian Journal of Pulses Research, 11:144-150.

Singh. G., and Sekhon H.S. 2014.Integrated weed management in Pigeonpea [Cajanus cajan (L.) Millisp.].World J.Agric.Sci. 9(1):86-91. 
Srinivasan, K., and Sankaran,N. 2001.Sulphur management in black gram and its effect on yield and economics. Madras Agricultural Journal, 88(10-12):654656.

Subramani, M., Solaimalai, A.and Velayutham, 2002. Effect of plant population and methods of fertilizer application on yield attributes and yield of irrigated black gram. Madras Agric.J., 89 (4-6):305-306.

Thesiya, N.M., Chovatia, P.K. and Kikani, V.L. 2013. Effect of potassium and sulphur on growth and yield of blackgram (Vigna mungo) under rain fed condition. Legume Research, 36(3):255-258.

Upadhay, V.B., and Bhalla, C.S., 2002.Efficacy of cultural and mechanical and chemical weed control in chickpea (Cicer arietinum L.). Indian
Journal of weed science, 34:141-142.

Veeramani, A., Palachamy A, Ramasamy S and Rangaraju G.2000.Integrated weed management in soyabean (Glycine max) under different moisture regimes and population densities. Indian Journal of Agronomy, 45(4):740-745.

Vivek, N.S., Rana, R.S.and Tomar, s.s.2008.Effect of weed interference on weeds and productivity of Blackgram (Phaseolous mungo). Indian Journal of weed science. 40(1\&2):65-67.

Yadav, S.P., and Shrivastava, U.K.1997. Response of chickpea (Cicer arietinum) to Phosphours and biofertilizer. Legume Research, 20(2):137-140.

Yadav, K.S., Dixit, J.P., and Prajapati, B.L. 2015. Weed management effects on yield and economics of blackgram. Indian Journal of Weed science. 47(2):136-138.

\section{How to cite this article:}

Monika Banotra, B.C. Sharma, Brij Nandan, Rakesh Kumar and Akhil Verma. 2017. A Critical Review on Improved Technologies for Maximization of Pulses Production in Rain Fed Areas. Int.J.Curr.Microbiol.App.Sci. 6(10): 2764-2774. doi: https://doi.org/10.20546/ijcmas.2017.610.324 